\title{
Selection of an algorithms controlling operation of supercharged compression ignition engine with additional fueling with CNG gas
}

The article presents an issues concerning selection of controlling algorithms for operation of supercharged compression ignition engine fueled additionally with CNG gas, including implemented control procedures, adjustment algorithms and operational algorithms. As the result, the engine which is run in dual fuel system operates under control of two controllers, factory ECU controller, governing fueling with the base fuel (Diesel oil) and all fueling parameters, and the second controller for gaseous fuel supply. Priority of operation of the controllers relates to fueling with Diesel oil, while the gas is treated as supplementary fuel. Due to possibility of usage of factorymade original ECU controller as used with Diesel oil supply; it has been presented proposal of its software in form of array algorithms.

Key words: compressed natural gas, dual fuel engine, work parameters, toxicity, smoke, engine controlling

\section{Introduction}

The main objective of the study was to assess a possibility of reducing smoke in exhaust gases by small additive of CNG natural gas. Reduction of the smoke in exhaust gases leads to reduction of emission of PM particulate matter, component of exhaust gases considered as highly toxic and the most severely restricted by international regulations concerning the problem of toxicity of exhaust gases [1, 3-6, 11-13, 16]. At the same time, the smoke comprising soot as its main component, is actually generating a big problem in operation of compression ignition engines in transient, urban driving conditions, especially during winter season [2, 10, 12, 15]. Excessive smoke, and thus emission of particulate matter under these conditions result in increased frequency of DPF filter regeneration, what reduces its service life and generates emission of toxic compounds during the regeneration. The utilitarian objectives of the study were to evaluate potential for partial substitution of liquid fuel by gas, to determine what are safe shares of the gas assuring correct operation of the engine and maintaining its service life, as well as developing of a map with control parameters of dual fuel engine in scope of fueling with Diesel oil and gas, which would be possible to be implemented in traction engines. Developed maps can be used to programming of already existing control systems, governing operation of EUS engine, or to construction of a new systems during adaptation of traction engines to dual fuel supply, provided that these engines are equipped with electronic injection systems of liquid and gaseous fuel.

The research was performed within framework of the Project No. PBS1/A6/13/2012 funded by NCB\&R on a serial engine of Fiat 1.3 MJT type. The study assumes that the main control parameters for dual fuel engine supply should be:

- division method of unit dose of Diesel oil in range of quantity and size of partial doses;

- injection advance angle of the first initial dose and delay angles of remaining doses;

- size of the dose and injection parameters of natural gas.

These parameters were investigated in complete range of engine operation, what results from its destination as a traction engine. It has been assumed that total dose of Die- sel oil should vary from nominal dose of traditional fueling within limits of about $40 \%$ for minimal engine load, and up to about $70 \%$ in area of maximal engine loads. Assumed dose resulted from necessity to ensure knocking-free engine operation in complete field of engine operation, and to maintain temperature of exhaust gases within acceptable limits. Such assumptions should assure failure-free operation of dual fuel engine over a long period of time. High energetic shares of natural gas at partial engine loads, up to $60 \%$, should ensure a significant operational exchangeability of liquid fuel by gas, what due to difference in price of the both fuels should bring significant operational savings of the engines.

\section{Research stand}

As object of the research work was used supercharged compression ignition engine of FIAT 1.3 MJT type, destined to powering of passenger cars from compact class. The engine is equipped with second generation, direct injection system Common Rail (CR) with division of the dose, so called Multi Jet. The Multi Jet injection technology enables active changing of injection characteristic of Diesel oil, resulting in reduction of engine noise, reduction of harmful emissions and improved engine performance. In this engine is used turbocompressor with constant geometry. Controlling of boost pressure is performed with use of wastegate valve, based on pressure of intake manifold. The supercharged air is cooled. The FIAT 1.3 MJT engine complies with EURO 4 emission standards, owing to EGR valve with cooler of recirculated exhaust gases. Technical parameters of this engine are presented in the Table 1.

Table 1. Technical specification of Fiat 1.3 MJT engine [19]

\begin{tabular}{|l|c|}
\hline Engine type & $1.3 \mathrm{MJT}$ \\
\hline Bore $\mathrm{x}$ stroke & $69.6 \times 82 \mathrm{~mm}$ \\
\hline Displacement & $1248 \mathrm{~cm}^{3}$ \\
\hline Number of cylinder & 4 \\
\hline Compression ratio & 18 \\
\hline Maximum power & $51 \mathrm{~kW}$ przy $4000 \mathrm{rpm}$ \\
\hline Maximum torque & $180 \mathrm{Nm}$ przy $1750 \mathrm{rpm}$ \\
\hline Injection system & Common Rail \\
\hline Number of valve per cylinder & 4 \\
\hline Timing system & DOHC \\
\hline Exhaust gas recirculation & EGR valve \\
\hline
\end{tabular}


a)

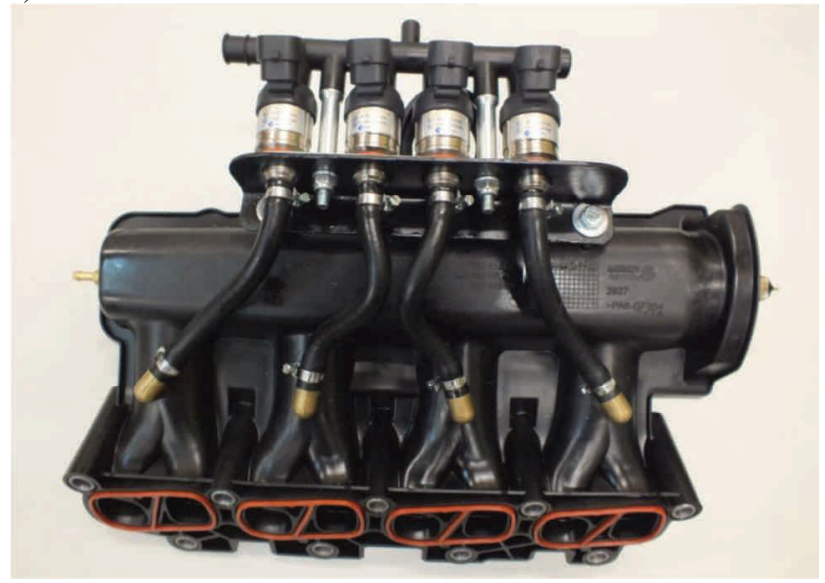

b)

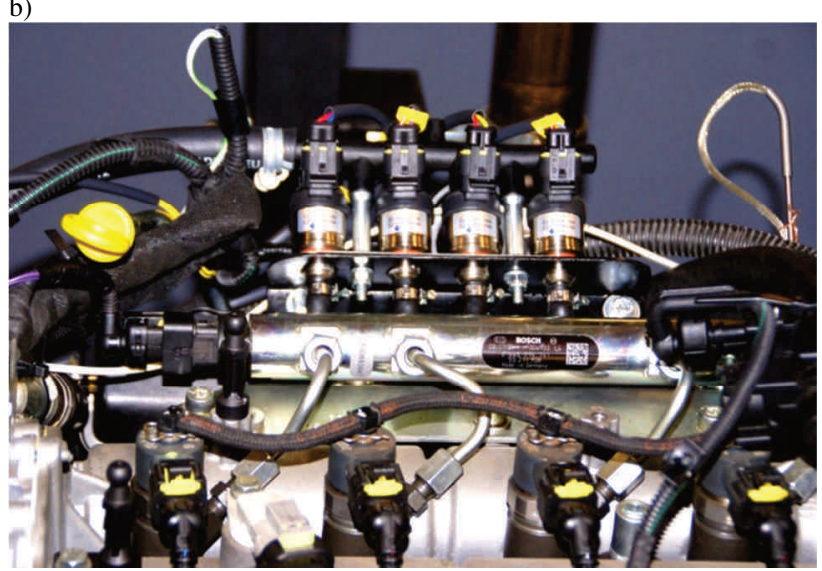

Fig. 1. Intake manifold and test stand of Fiat 1.3 MJT engine:a) intake manifold, b) engine Fiat $1.3 \mathrm{MJT}$ and all parameters of the supply, and $\mathrm{ECU}_{\mathrm{CNG}}$ controller for fueling with gas. Operational priority of the controllers concerns fueling with Diesel oil, while the gas is treated as a supplementary fuel [18].

\section{Selection of algorithms to controlling operation of dual fuel engine}

Additional controllers used with dual fuel systems in compression ignition engines are generally of all-purpose character and are dedicated to various engines. Such controllers comprise necessary software for strategic and controlling procedures, but in practical application they can differ in their availability, with suitable interfaces to these procedures and their abilities to shaping appropriate operational characteristics. The control system used in the research work required usage of two controllers, factory made $\mathrm{ECU}_{\mathrm{DO}}$ controller, governing injection of Diesel oil and other fueling parameters, and $\mathrm{ECU}_{\mathrm{CNG}}$ controller, to feeding with gas and performing injection of gas in accordance with programmed operational characteristics. The controller enables displaying of the following messages about exceeded preset parameters. Below is the list of all monitored messages:

- maximal temperature of exhaust gases,

- maximal level of knocking,

- lacking thermo-couple,

- high or low temperature of the reducer,

- low pressure of gas,

- low or high MAP pressure,

- low or high voltage of battery,

- low temperature of gas,

- low rotational speed of the engine,
The engine was adapted for simultaneous combustion of two fuels natural gas and Diesel oil. It was used a prototype inlet manifold with four injectors of gas, enabling sequential injection of gas in area close to inlet valves. Moreover, it have been installed additional pipes (with coolant, supplying gas and air), and wiring harness connecting gas supply installation with the ECU and with the engine $[17,18,20]$. View of prototype manifold and the engine is shown in the Fig. 1.

Commercially available system of Oscar-N Diesel SAS type was used in adaptation of the engine [20]. It is a system of sequential ignition of gas (CNG or LPG) developed by EuropeGas Company, destined to compression ignition engines. The main components of this system are presented in the Fig. 2.

In result, the engine run in dual fuel supply system operated under control of two controllers: factory-made ECUDo, controlling the neat fuel (Diesel oil)

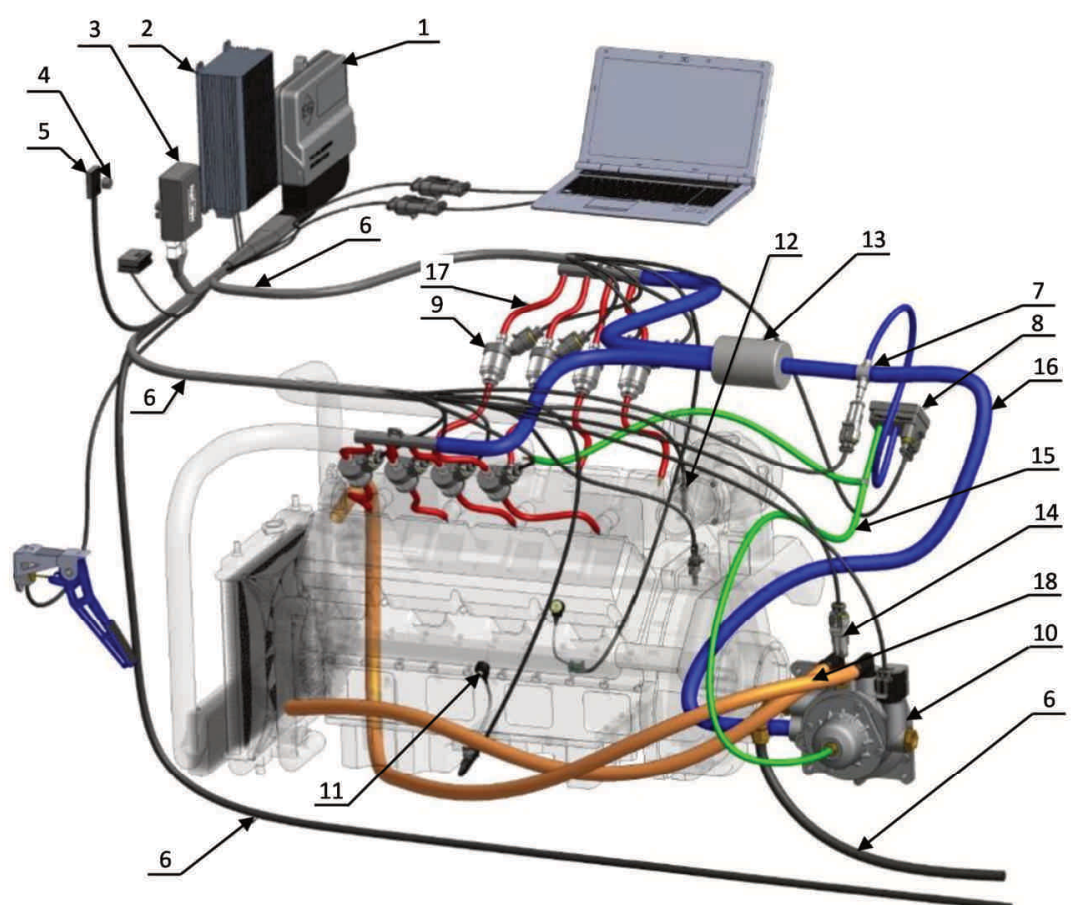

Fig. 2. Scheme of installation of CNG supply of OSCAR-N Diesel SAS type [20]: 1 - controller, 2 power supply of the system- inverter $24 \mathrm{~V} / 12 \mathrm{~V}$ - DC/DC, 3 - emulator TPS, 4 - buzzer, 5 - switch, 6 - wiring harness, 7 - measuring Tee, 8 - MAP sensor, 9 - injectors, 10 - reducer, 11 - knocking sensor, 12 - thermocouple, 13 - filter of violate phase, 14 - sensor of reducer's temperature, 15 - pipe - pressure in the manifold, 16 - pipe - low pressure of gas, 17 - pipe - low pressure of gas, 18 - pipe - heating of reducer, 19 - high-pressure pipe - supply of gas from bottle 
- high rotational speed of the engine,

- high outlet temperature of exhaust gases,

- high level of knocking,

- lacking rotational speed,

- braking with engine,

- too short injection times of gas,

- too long injection times of gas,

- electro-valves switched on,

- pilot injection,

- emergency switch-off the system,

- recorded errors of the system, (message is displayed when in the controller's memory are written errors),

- emulators active.

Obviously, it would be possible to develop a single controller which would govern program of engine fueling, but it would require stipulations with many engine manufacturers, and due to it, such method of controlling would not be all-purpose. The Oscar-N Diesel SAS system, along with the controller, features many advantages such as: precise and safe supply with gas, easy installation of gaseous system, sequential mode of injection, short injection times, control of injection pressure of the gas, and ability of emulation of "accelerator pedal", programmable control algorithms of array type, and operational algorithms, which in all states and conditions of engine operation can jointly control injection of gas in dual fuel engine with compression ignition. Control of Diesel oil injection was accomplished on the basis of factory controller without interfering with its controlling parameters. Such approach in the research process should reflect commonly used, classical way of accomplishment of commercial dual fuel installations in compression ignition engines.

Selection of parameters of the control algorithms to dual fuel engine has comprised the following control functions:

- Control of opening times of injectors and values of injection advance angle for individual portions of Diesel oil: Pilot, Pre, and Main;

- Control of fuel pressure value in Common Rail and value of boost pressure inside inlet manifold (accomplished by control of turbocompressor unit),

- Control of opening time of CNG gas injectors.

Above mentioned parameters were controlled in function of position of accelerator lever (ACC - accelerator) and rotational speed of the engine $(n)$.

The tables of the above algorithms have 81 fields in $9 x$ 9 coordinate system. Tables $2-4$ show values of the control algorithms of opening times of injectors for individual portions of the dose of Diesel oil at dual fuel supply. Specified values take into consideration reduction of total quantities of injected Diesel oil due to additive of gas, in relation to the engine run on neat Diesel oil. Using colours are marked in the tables such areas of the control parameters having influence on reduction of beneficial effects resulting from additive of CNG gas.

Tables 5-7 show values of the control algorithms of injection advance angle for each portions of Diesel oil dose at dual fuel supply. These values are similar to the values used in the engine run on Diesel oil only. There was none possibility to change value of this parameter in course of the investigations. It resulted solely from algorithms written and executed for supply with Diesel oil by factory-installed controller of the engine. As in case of the previous arrays, with colour are marked areas of control parameters having influence on reduction of beneficial effects resulting from additive of CNG gas.

Table 2. Control algorithm of opening time of Diesel oil injectors for Pilot dose at dual fuel supply of the engine

\begin{tabular}{|c|c|c|c|c|c|c|c|c|c|}
\hline \multicolumn{10}{|c|}{ Pilot injection timing - diesel oil [us] } \\
\hline $\mathbf{1 0 0}$ & 320 & 350 & 0 & 0 & 0 & 0 & 0 & 0 & 0 \\
\hline $\mathbf{7 5}$ & 220 & 350 & 0 & 0 & 0 & 0 & 0 & 0 & 0 \\
\hline $\mathbf{5 5}$ & 315 & 350 & 0 & 0 & 0 & 0 & 0 & 0 & 0 \\
\hline $\mathbf{4 0}$ & 315 & 345 & 0 & 0 & 0 & 0 & 0 & 0 & 0 \\
\hline $\mathbf{3 0}$ & 310 & 0 & 0 & 0 & 0 & 0 & 0 & 0 & 0 \\
\hline $\mathbf{2 0}$ & 310 & 0 & 0 & 0 & 0 & 0 & 0 & 0 & 0 \\
\hline $\mathbf{1 5}$ & 310 & 325 & 0 & 0 & 0 & 0 & 0 & 0 & 0 \\
\hline $\mathbf{1 0}$ & 320 & 330 & 0 & 0 & 0 & 0 & 0 & 0 & 0 \\
\hline $\mathbf{5}$ & 320 & 330 & 0 & 0 & 0 & 0 & 0 & 0 & 0 \\
\hline \multirow{2}{*}{ ACC [\%] } & $\mathbf{1 0 0 0}$ & $\mathbf{1 5 0 0}$ & $\mathbf{2 0 0 0}$ & $\mathbf{2 5 0 0}$ & $\mathbf{3 0 0 0}$ & $\mathbf{3 5 0 0}$ & $\mathbf{4 0 0 0}$ & $\mathbf{4 5 0 0}$ & $\mathbf{5 0 0 0}$ \\
\cline { 2 - 8 } & \multicolumn{10}{|c|}{ Engine speed n[rpm] } \\
\hline
\end{tabular}

Table 3. Control algorithm of opening time of Diesel oil injectors for Pre dose at dual fuel supply of the engine

\begin{tabular}{|c|c|c|c|c|c|c|c|c|c|}
\hline \multicolumn{10}{|c|}{ Pre injection timing - diesel oil $[\mu \mathrm{s}]$} \\
\hline 100 & 290 & 290 & 277 & 274 & 240 & 0 & 0 & 0 & 0 \\
\hline 75 & 290 & 290 & 277 & 274 & 240 & 0 & 0 & 0 & 0 \\
\hline 55 & 290 & 295 & 277 & 274 & 240 & 255 & 215 & 0 & 0 \\
\hline 40 & 290 & 295 & 278 & 275 & 255 & 265 & 215 & 0 & 0 \\
\hline 30 & 295 & 300 & 285 & 278 & 275 & 265 & 220 & 0 & 0 \\
\hline 20 & 295 & 320 & 280 & 280 & 275 & 270 & 220 & 0 & 0 \\
\hline 15 & 295 & 325 & 288 & 300 & 280 & 275 & 225 & 0 & 0 \\
\hline 10 & 325 & 335 & 300 & 320 & 330 & 280 & 230 & 0 & 0 \\
\hline 5 & 330 & 340 & 310 & 330 & 335 & 285 & 235 & 0 & 0 \\
\hline \multirow{2}{*}{$\mathrm{ACC}[\%]$} & 1000 & 1500 & 2000 & 2500 & 3000 & 3500 & 4000 & 4500 & 5000 \\
\hline & \multicolumn{9}{|c|}{ Engine speed n [rpm] } \\
\hline
\end{tabular}

Table 4. Control algorithm of opening time of Diesel oil injectors for Main dose at dual fuel supply of the engine

\begin{tabular}{|c|c|c|c|c|c|c|c|c|c|}
\hline \multicolumn{10}{|c|}{ Main injection timing - diesel oil $[\mu \mathrm{s}]$} \\
\hline 100 & 780 & 830 & 910 & 910 & 860 & 725 & 670 & 655 & 605 \\
\hline 75 & 750 & 780 & 850 & 810 & 790 & 725 & 670 & 625 & 600 \\
\hline 55 & 630 & 680 & 730 & 705 & 685 & 620 & 620 & 610 & 590 \\
\hline 40 & 595 & 600 & 670 & 660 & 640 & 585 & 575 & 565 & 540 \\
\hline 30 & 555 & 570 & 620 & 630 & 600 & 535 & 540 & 545 & 530 \\
\hline 20 & 505 & 525 & 590 & 560 & 540 & 495 & 495 & 490 & 480 \\
\hline 15 & 475 & 500 & 545 & 510 & 495 & 460 & 470 & 480 & 465 \\
\hline 10 & 440 & 460 & 500 & 460 & 450 & 430 & 440 & 450 & 430 \\
\hline 5 & 345 & 355 & 390 & 380 & 380 & 360 & 355 & 415 & 400 \\
\hline \multirow{2}{*}{$\mathrm{ACC}[\%]$} & 1000 & 1500 & 2000 & 2500 & 3000 & 3500 & 4000 & 4500 & 5000 \\
\hline & \multicolumn{9}{|c|}{ Engine speed n [rpm] } \\
\hline
\end{tabular}

Table 5. Control algorithm of injection advance angle of Diesel oil for Pilot dose at dual fuel supply of the engine

\begin{tabular}{|c|c|c|c|c|c|c|c|c|c|}
\hline \multicolumn{10}{|c|}{ Angle advance of injection pilot ${ }^{\circ}{ }^{\circ}$} \\
\hline $\mathbf{1 0 0}$ & 12 & 48 & - & - & - & - & - & - & - \\
\hline $\mathbf{7 5}$ & 10 & 48 & - & - & - & - & - & - & - \\
\hline $\mathbf{5 5}$ & 8 & 19 & - & - & - & - & - & - & - \\
\hline $\mathbf{4 0}$ & 8 & 19 & - & - & - & - & - & - & - \\
\hline $\mathbf{3 0}$ & 7 & - & - & - & - & - & - & - & - \\
\hline $\mathbf{2 0}$ & 8 & - & - & - & - & - & - & - & - \\
\hline $\mathbf{1 5}$ & 8 & 16 & - & - & - & - & - & - & - \\
\hline $\mathbf{1 0}$ & 8 & 19 & - & - & - & - & - & - & - \\
\hline $\mathbf{5}$ & 8 & 18 & - & - & - & - & - & - & - \\
\hline \multirow{2}{*}{ ACC [\%] } & $\mathbf{1 0 0 0}$ & 1500 & $\mathbf{2 0 0 0}$ & $\mathbf{2 5 0 0}$ & $\mathbf{3 0 0 0}$ & $\mathbf{3 5 0 0}$ & $\mathbf{4 0 0 0}$ & $\mathbf{4 5 0 0}$ & $\mathbf{5 0 0 0}$ \\
\cline { 2 - 8 } & \multicolumn{8}{|c|}{ Engine speed n [rpm] } \\
\hline
\end{tabular}


Selection of an algorithms controlling operation of supercharged compression ignition engine with additional fueling with CNG gas

Table 6. Control algorithm of injection advance angle of Diesel oil for Pre dose at dual fuel supply of the engine

\begin{tabular}{|c|c|c|c|c|c|c|c|c|c|}
\hline \multicolumn{10}{|c|}{ Angle advance of injection Pre [ $\left.{ }^{\circ}\right]$} \\
\hline $\mathbf{1 0 0}$ & 8 & 8 & 10 & 17 & 25 & - & - & - & - \\
\hline $\mathbf{7 5}$ & 8 & 8 & 10 & 17 & 22 & - & - & - & - \\
\hline $\mathbf{5 5}$ & 6 & 7 & 9 & 14 & 20 & 28 & 32 & - & - \\
\hline $\mathbf{4 0}$ & 6 & 7 & 8 & 12 & 19 & 28 & 30 & - & - \\
\hline $\mathbf{3 0}$ & 5 & 7 & 8 & 11 & 19 & 26 & 29 & - & - \\
\hline $\mathbf{2 0}$ & 5 & 7 & 8 & 12 & 18 & 25 & 29 & - & - \\
\hline $\mathbf{1 5}$ & 5 & 7 & 9 & 12 & 18 & 25 & 29 & - & - \\
\hline $\mathbf{1 0}$ & 6 & 7 & 10 & 13 & 18 & 25 & 29 & - & - \\
\hline $\mathbf{5}$ & 6 & 7 & 10 & 13 & 18 & 25 & 29 & - & - \\
\hline \multirow{2}{*}{ ACC $[\%]$} & $\mathbf{1 0 0 0}$ & $\mathbf{1 5 0 0}$ & $\mathbf{2 0 0 0}$ & $\mathbf{2 5 0 0}$ & $\mathbf{3 0 0 0}$ & $\mathbf{3 5 0 0}$ & $\mathbf{4 0 0 0}$ & $\mathbf{4 5 0 0}$ & $\mathbf{5 0 0 0}$ \\
\cline { 2 - 9 } & \multicolumn{8}{|c|}{ Engine speed n [rpm] } \\
\hline
\end{tabular}

Table.7. Control algorithm of injection advance angle of Diesel oil for Main dose at dual fuel supply of the engine

\begin{tabular}{|c|c|c|c|c|c|c|c|c|c|}
\hline \multicolumn{10}{|c|}{ Angle advance of injection Main [ $\left.{ }^{\circ}\right]$} \\
\hline $\mathbf{1 0 0}$ & 3 & 3 & 5 & 9 & 15 & 21 & 24 & 27 & 28 \\
\hline $\mathbf{7 5}$ & 2 & 3 & 4 & 9 & 13 & 20 & 23 & 25 & 27 \\
\hline $\mathbf{5 5}$ & 2 & 2 & 3 & 6 & 10 & 17 & 21 & 24 & 26 \\
\hline $\mathbf{4 0}$ & 1 & 2 & 2 & 4 & 10 & 16 & 19 & 22 & 25 \\
\hline $\mathbf{3 0}$ & 1 & 2 & 2 & 3 & 9 & 15 & 18 & 21 & 25 \\
\hline $\mathbf{2 0}$ & 1 & 1 & 2 & 4 & 9 & 15 & 17 & 20 & 25 \\
\hline $\mathbf{1 5}$ & 1 & 2 & 2 & 5 & 9 & 15 & 17 & 20 & 23 \\
\hline $\mathbf{1 0}$ & 2 & 2 & 3 & 6 & 9 & 15 & 17 & 20 & 23 \\
\hline $\mathbf{5}$ & 2 & 2 & 3 & 6 & 9 & 15 & 17 & 20 & 23 \\
\hline \multirow{2}{*}{ ACC [\%] } & $\mathbf{1 0 0 0}$ & $\mathbf{1 5 0 0}$ & $\mathbf{2 0 0 0}$ & $\mathbf{2 5 0 0}$ & $\mathbf{3 0 0 0}$ & $\mathbf{3 5 0 0}$ & $\mathbf{4 0 0 0}$ & $\mathbf{4 5 0 0}$ & $\mathbf{5 0 0 0}$ \\
\cline { 2 - 9 } & \multicolumn{8}{|c|}{ Engine speed n [rpm] } \\
\hline
\end{tabular}

Table 8 shows values of control algorithms of fuel pressure in Common Rail of Diesel oil at dual fuel feeding.

Table 8. Control algorithm of fuel pressure in Common Rail at dual fuel supply of the engine

\begin{tabular}{|c|c|c|c|c|c|c|c|c|c|}
\hline \multicolumn{10}{|c|}{ Fuel pressure [bar] } \\
\hline $\mathbf{1 0 0}$ & 750 & 830 & 1000 & 1100 & 1210 & 1380 & 1590 & 1590 & 1590 \\
\hline $\mathbf{7 5}$ & 730 & 810 & 990 & 1100 & 1200 & 1360 & 1580 & 1550 & 1520 \\
\hline $\mathbf{5 5}$ & 690 & 790 & 980 & 1105 & 1200 & 1310 & 1370 & 1360 & 1360 \\
\hline $\mathbf{4 0}$ & 630 & 740 & 960 & 1090 & 1180 & 1200 & 1200 & 1190 & 1140 \\
\hline $\mathbf{3 0}$ & 580 & 680 & 930 & 1040 & 1090 & 1100 & 180 & 1050 & 1040 \\
\hline $\mathbf{2 0}$ & 490 & 520 & 750 & 930 & 1020 & 1000 & 980 & 910 & 910 \\
\hline $\mathbf{1 5}$ & 440 & 470 & 620 & 790 & 910 & 920 & 880 & 840 & 840 \\
\hline $\mathbf{1 0}$ & 390 & 430 & 500 & 650 & 750 & 790 & 790 & 780 & 780 \\
\hline $\mathbf{5}$ & 300 & 390 & 440 & 540 & 610 & 690 & 680 & 660 & 650 \\
\hline \multirow{2}{*}{ ACC $[\%]$} & $\mathbf{1 0 0 0}$ & $\mathbf{1 5 0 0}$ & $\mathbf{2 0 0 0}$ & $\mathbf{2 5 0 0}$ & $\mathbf{3 0 0 0}$ & $\mathbf{3 5 0 0}$ & $\mathbf{4 0 0 0}$ & $\mathbf{4 5 0 0}$ & $\mathbf{5 0 0 0}$ \\
\cline { 2 - 7 } & \multicolumn{1000}{|c|}{ Engine speed n [rpm] } \\
\hline
\end{tabular}

Table 9 presents values of control algorithms for opening time of CNG gas injectors. Although values of the opening times are practically at the same level, in practice the value of injected gas has undergone a bigger change. It results from fact of continuous correction of injection pressure of the gas based on pressure change in the intake manifold. Despite such adjustment, share of the gas in total quantities of supplied fuel varies significantly. At low engine loads share of the gas is bigger and decreases with increasing engine load.

It was very important to develop an algorithm to control value of air boost pressure in the intake manifold. In order to restrict emissions of the particulate matter and smoke, it was necessary to verify operation of turbocharger assembly, and its controlling to assure supply of the same mass of the air at dual fuel supply as in case of fueling with Diesel oil only. Values of control algorithm of the boost pressure are presented in Table 10 .
Table 9. Control algorithm of opening time of CNG gas injectors at dual fuel supply of the engine

\begin{tabular}{|c|c|c|c|c|c|c|c|c|c|}
\hline \multicolumn{10}{|c|}{ Pilot injection timing - CNG [ms] } \\
\hline $\mathbf{1 0 0}$ & 1,0 & 1,0 & 1,0 & 1,5 & 2,0 & 2,0 & 2,0 & 2,0 & 2,0 \\
\hline $\mathbf{7 5}$ & 1,0 & 1,0 & 1,0 & 1,5 & 2,0 & 2,0 & 2,0 & 2,0 & 2,0 \\
\hline $\mathbf{5 5}$ & 1,0 & 1,0 & 1,5 & 1,5 & 2,0 & 2,0 & 2,0 & 2,0 & 2,0 \\
\hline $\mathbf{4 0}$ & 1,0 & 1,5 & 1,5 & 2,0 & 2,0 & 2,0 & 2,0 & 2,0 & 2,0 \\
\hline $\mathbf{3 0}$ & 1,0 & 1,5 & 1,5 & 2,0 & 2,0 & 2,0 & 2,0 & 2,0 & 2,0 \\
\hline $\mathbf{2 0}$ & 1,5 & 1,5 & 2,0 & 2,0 & 2,0 & 2,0 & 2,0 & 2,0 & 2,0 \\
\hline $\mathbf{1 5}$ & 1,5 & 2,0 & 2,0 & 2,0 & 2,0 & 2,0 & 2,0 & 2,0 & 2,0 \\
\hline $\mathbf{1 0}$ & 2,0 & 2,0 & 2,0 & 2,0 & 2,0 & 2,0 & 2,0 & 2,0 & 2,0 \\
\hline $\mathbf{5}$ & 2,0 & 2,0 & 2,0 & 2,0 & 2,0 & 2,0 & 2,0 & 2,0 & 2,0 \\
\hline \multirow{2}{*}{ ACC $[\%]$} & $\mathbf{1 0 0 0}$ & $\mathbf{1 5 0 0}$ & $\mathbf{2 0 0 0}$ & $\mathbf{2 5 0 0}$ & $\mathbf{3 0 0 0}$ & $\mathbf{3 5 0 0}$ & $\mathbf{4 0 0 0}$ & $\mathbf{4 5 0 0}$ & $\mathbf{5 0 0 0}$ \\
\cline { 2 - 7 } & \multicolumn{8}{|c|}{ Engine speed n [rpm] } \\
\hline
\end{tabular}

Table 10. Control algorithm of fuel pressure in Common Rail at dual fuel supply of the engine

\begin{tabular}{|c|c|c|c|c|c|c|c|c|c|}
\hline \multicolumn{10}{|c|}{ Boost pressure [mbar] } \\
\hline $\mathbf{1 0 0}$ & 1700 & 1840 & 1880 & 2000 & 2000 & 1960 & 1900 & 1780 & 1700 \\
\hline $\mathbf{7 5}$ & 1580 & 1760 & 1860 & 2000 & 1920 & 1880 & 1860 & 1720 & 1660 \\
\hline $\mathbf{5 5}$ & 1440 & 1580 & 1620 & 1820 & 1860 & 1840 & 1820 & 1680 & 1620 \\
\hline $\mathbf{4 0}$ & 1280 & 1400 & 1520 & 1750 & 1700 & 1640 & 1620 & 1600 & 1540 \\
\hline $\mathbf{3 0}$ & 1200 & 1260 & 1400 & 1640 & 1620 & 1600 & 1540 & 1520 & 1450 \\
\hline $\mathbf{2 0}$ & 1120 & 1140 & 1320 & 1500 & 1440 & 1500 & 1480 & 1480 & 1360 \\
\hline $\mathbf{1 5}$ & 1050 & 1100 & 1280 & 1360 & 1400 & 1440 & 1430 & 1420 & 1320 \\
\hline $\mathbf{1 0}$ & 980 & 1050 & 1200 & 1280 & 1380 & 1400 & 1390 & 1380 & 1280 \\
\hline $\mathbf{5}$ & 900 & 1000 & 1100 & 1190 & 1240 & 1220 & 1210 & 1200 & 1200 \\
\hline $\mathbf{A C C}$ & $\mathbf{1 0 0 0}$ & $\mathbf{1 5 0 0}$ & $\mathbf{2 0 0 0}$ & $\mathbf{2 5 0 0}$ & $\mathbf{3 0 0 0}$ & $\mathbf{3 5 0 0}$ & $\mathbf{4 0 0 0}$ & $\mathbf{4 5 0 0}$ & $\mathbf{5 0 0 0}$ \\
\cline { 2 - 2 } & \multicolumn{10}{|c|}{ Engine speed n [rpm] } \\
\hline
\end{tabular}

As seen from performed studies, system of additional supply with gas, co-acting with factory controller of Diesel oil, for which the control algorithms are presented above, has got several disadvantages limiting full usage of beneficial effect of addition of CNG gas. The disadvantages include, among others: division of dose into three partial doses Pilot, Pre and Main, too small size of Pre dose, incorrect injection advance angle of Pre dose, too big delay in injection of Main dose, lacking control over recirculation of exhaust gases and lacking possibility of control over supercharging (volumes of supplied air) [18]. Supply of additional fuel in form of gas is resulting, as a rule, in shift of operational point of the engine in control algorithms of Diesel oil to direction of lower loads, as a result of smaller amount of air supplied to the engine (reduction of boost pressure and simultaneous increase of EGR). Since two fuels (Diesel oil $+\mathrm{CNG}$ ) are supplied to the engine for proper engine load in conditions of reduced quantity of supplied air, it results in increased level of smoke in exhaust gases at some points of engine operation [16, 17]. Also in case of additional fueling with CNG gas, division methods of Diesel oil dose as implemented in the factory controllers, as well as advance angle of individual portions of the dose, are unsuitable for system of the dual fuel supply. In the control algorithms of Diesel oil, shown in Tables 2 to 7 , using colour are marked areas of incorrect control parameters.

The above mentioned drawbacks necessitate interfering with software of the factory controller, or developing controller of gas in such way as to allow such overlapping correction of control parameters of Diesel oil, which would allow proper method of dual fuel supply of the engine. These changes are aimed at full use of positive effect of addition of gas in combustion process of Diesel oil. Below 
are presented control algorithms of Diesel oil, taking into account proposed changes in parameters of control algorithms contained in the Tables 2 to 7 , in tables marked with colour. They concern the following changes:

- completely switched off Pilot dose,

- increased size of portion of Pre fuel dose.

In Tables 11 to 12 are presented proposed values of the control algorithms of opening times of injectors for individual portions of Diesel oil for dual fuel supply (Table 11). Whereas, increase in value of switched off Pilot dose was seen in area marked with more dark colour in the Table 3. Proposed value of opening time of injectors is not the sum of the values from Tables 2 and 3, because in these Arrays are included values of control times, while during evaluation of the times from Table 11, mass of injected fuel per cycle was summed up. Considering specifics of control process of injectors operation, control time of injector operation after summation of the doses will always be lower than sums of the times. In turn, in area marked in lighter colour in the Table 3 , increase in value of portion of the dose Pre occurred at the expense of reduced value of portion of the dose Main. Hence, are seen differences in control times both in Table 11 and Table 12, relative to the values specified respectively in Tables 3 and 4.

Table 11. Corrected control algorithm of opening time of Diesel oil injectors for Pre dose at dual fuel supply of the engine

\begin{tabular}{|c|c|c|c|c|c|c|c|c|c|}
\hline \multicolumn{10}{|c|}{ Pre injection timing - CNG [ $\mu \mathrm{s}]$} \\
\hline 100 & 400 & 405 & 375 & \begin{tabular}{|l|l}
375 \\
\end{tabular} & 370 & 0 & 0 & 0,0 & 0,0 \\
\hline 75 & 400 & 415 & 375 & 375 & 375 & 0 & 0 & 0,0 & 0,0 \\
\hline 55 & 380 & 400 & 380 & 380 & 375 & 375 & 365 & 0,0 & 0,0 \\
\hline 40 & 365 & 395 & 380 & 380 & 375 & 375 & 365 & 0,0 & 0,0 \\
\hline 30 & 360 & 390 & 385 & 380 & 380 & 375 & 370 & 0,0 & 0,0 \\
\hline 20 & 375 & 390 & 380 & 380 & 380 & 375 & 370 & 0,0 & 0,0 \\
\hline 15 & 385 & 400 & 385 & 385 & 380 & 380 & 375 & 0,0 & 0,0 \\
\hline 10 & 400 & 405 & 390 & 390 & 380 & 380 & 380 & 0,0 & 0,0 \\
\hline 5 & 405 & 405 & 400 & 390 & 385 & 380 & 380 & 0,0 & 0,0 \\
\hline ACC & 1000 & 1500 & 2000 & 2500 & 3000 & 3500 & 4000 & 4500 & 5000 \\
\hline$[\%]$ & & & & & see & $\mid \mathbf{r p}$ & & & \\
\hline
\end{tabular}

Table 12. Corrected control algorithm of opening time of Diesel oil injectors for Main dose at dual fuel supply of the engine

\begin{tabular}{|c|c|c|c|c|c|c|c|c|c|}
\hline \multicolumn{10}{|c|}{ Main injection timing - CNG [ $\mu \mathrm{s}]$} \\
\hline 100,0 & 780 & 830 & 865 & 865 & 815 & 725 & 670 & 655 & 605 \\
\hline 75,0 & 750 & 780 & 795 & 760 & 745 & 725 & 670 & 625 & 600 \\
\hline 55,0 & 630 & 680 & 675 & 655 & 640 & 620 & 620 & 610 & 590 \\
\hline 40,0 & 595 & 600 & 615 & 625 & 605 & 585 & 530 & 565 & 540 \\
\hline 30,0 & 555 & 535 & 585 & 585 & 565 & 500 & 505 & 545 & 530 \\
\hline 20,0 & 505 & 500 & 555 & 525 & 515 & 475 & 475 & 490 & 480 \\
\hline 15,0 & 475 & 500 & 515 & 485 & 475 & 445 & 450 & 480 & 465 \\
\hline 10,0 & 440 & 460 & 465 & 440 & 410 & 410 & 405 & 450 & 430 \\
\hline 5,0 & 345 & 355 & 365 & 365 & 355 & 335 & 325 & 415 & 400 \\
\hline $\mathbf{A C C}$ & 1000 & 1500 & 2000 & 2500 & 3000 & 3500 & 4000 & 4500 & 5000 \\
\hline$[\%]$ & \multicolumn{9}{|c|}{ Engine speed n [rpm] } \\
\hline
\end{tabular}

In Table 13 are presented proposed values of control algorithms of injection advance angle for individual portions of Diesel oil dose at dual fuel supply. The same as it was occurred in case of value of Pilot dose of liquid fuel, when the Pilot dose is switched off, the algorithm will not include value of injection advance angle. Presented here, proposed values of injection advance angle for the dose Pre were unchanged in relation to the values presented in Table 6 . In order to accelerate combustion process of portion of dose Main it was proposed a slight increase of the injection advance angle for this portion of the dose (Table 13) in relation to the values included within coloured area of Table 7. In addition, due to extended injection time of the dose Pre, real interval between end of the injection for portion of dose Pre, and beginning of injection of portion of dose Main will be much shorter than it would be resulted only from correction of the injection advance angle for portion of dose Main. Such approach was taken to restrict unfavorable phenomenon of ,reduction of oxygen concentration" by combusted gas contained in combustion chamber (ignition of gas occurs practically at beginning of self-ignition of dose Pre) before start of combustion of dose Main. This phenomenon has an effect on result of combustion of portion of dose Main in reduced concentration of oxygen, what leads to increased smoke in exhaust gases.

In case of numerical values of the algorithms: controlling fuel pressure in Common Rail, opening time of injectors of CNG gas, and air boost pressure inside intake manifold, none corrections were introduced for dual fuel supply in relation to Tables 8, 9 and 10. In particular, the control algorithm of air boost pressure inside intake manifold was especially developed during the experimental research, and the values presented in the Table 10 are values modified with respect to values programmed in the factory controller of Diesel oil.

Table 13. Proposed control algorithm of injection advance angle of Diesel oil for Main dose at dual fuel supply of the engine

\begin{tabular}{|c|c|c|c|c|c|c|c|c|c|}
\hline \multicolumn{10}{|c|}{ Angle advance of injection Main $\left[{ }^{\circ}\right]$} \\
\hline $\mathbf{1 0 0}$ & 4 & 4 & 6 & 11 & 17 & 21 & 24 & 27 & 28 \\
\hline $\mathbf{7 5}$ & 3 & 4 & 5 & 11 & 15 & 20 & 23 & 25 & 27 \\
\hline $\mathbf{5 5}$ & 3 & 3 & 4 & 8 & 12 & 20 & 24 & 24 & 26 \\
\hline $\mathbf{4 0}$ & 2 & 3 & 3 & 6 & 12 & 19 & 22 & 22 & 25 \\
\hline $\mathbf{3 0}$ & 2 & 3 & 3 & 5 & 11 & 18 & 21 & 21 & 25 \\
\hline $\mathbf{2 0}$ & 2 & 2 & 3 & 6 & 11 & 18 & 20 & 20 & 25 \\
\hline $\mathbf{1 5}$ & 2 & 3 & 3 & 7 & 11 & 18 & 20 & 20 & 23 \\
\hline $\mathbf{1 0}$ & 3 & 3 & 4 & 8 & 11 & 18 & 20 & 20 & 23 \\
\hline $\mathbf{5}$ & 3 & 3 & 4 & 8 & 11 & 18 & 20 & 20 & 23 \\
\hline $\begin{array}{c}\text { ACC } \\
{[\mathbf{1 0}]}\end{array}$ & $\mathbf{1 0 0 0}$ & $\mathbf{1 5 0 0}$ & $\mathbf{2 0 0 0}$ & $\mathbf{2 5 0 0}$ & $\mathbf{3 0 0 0}$ & $\mathbf{3 5 0 0}$ & $\mathbf{4 0 0 0}$ & $\mathbf{4 5 0 0}$ & $\mathbf{5 0 0 0}$ \\
\hline \multicolumn{10}{|c|}{ Engine speed n [rpm] } \\
\hline
\end{tabular}

Use of additive of gas and discussed changes in controlling of dual fuel engine resulted in significant changes in smoke in exhaust gases and emission of particulate matter, which was the primary objective of the research work performed within framework of the Project No. PBS1/A6/13/2012 financed by NCB\&R. changes in the smoke were investigated in static conditions, at the points determined by Mo-n (torque - rotational speed) representative for NEDC driving test [14].

Relative changes in the smoke, in comparison with Diesel oil, obtained at the points of NEDC test, were calculated from the formula:

$$
\delta S_{\mathrm{DF}}=100 \cdot \frac{\mathrm{S}_{\mathrm{DF}}-\mathrm{S}_{\mathrm{DO}}}{\mathrm{S}_{\mathrm{DO}}}[\%]
$$

where: $\delta \mathrm{S}_{\mathrm{DF}}$ - relative change in smoke in exhaust gases with correction of air output and with opening time of gas 
injector of $2.0 \mathrm{~ms}, \mathrm{~S}_{\mathrm{DF}}-$ smoke in exhaust gases from dual fuel engine at opening time of gas injector of $2.0 \mathrm{~ms}, \mathrm{~S}_{\mathrm{DO}}-$ smoke in exhaust gases from engine run on Diesel oil.

Relative changes in smoke shown in the Fig. 3 show at a big reduction of smoke both in conditions of urban driving Point 1-15, as well as extra-urban driving Point 16-20. Reduction of the smoke in urban conditions, especially when driving in low temperatures, will contribute to prolonged periods between successive regenerations of PDF filter, what will reduce emissions of toxic compounds generated during purification of this filter $[9,12,15]$. In addition, signaled by a drivers failure rate of engines with assembled DPF filters will be decreased, while operational periods between successive purifications of the DPF filter will be extended.

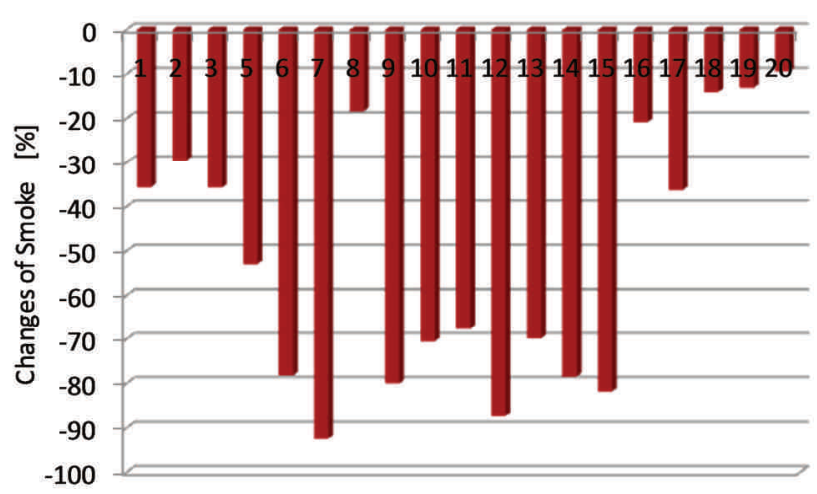

Fig. 3. Changes of smoke in exhaust gases of dual fuel engine at points simulating NEDC test in relation fueling with pure Diesel oil: correction of air output, opening time of gas injector $2.0 \mathrm{~ms}$

Reduction of the smoke is accompanied by reduced emission of particulate matter, what is shown in the Fig. 4. Especially high differences are present at a higher engine loads, Points 19 and 20, when the absolute emissions of exhaust gases are the highest. Relatively lower changes in the PN number of emitted particulate matter at partial engine loads, simultaneously with big changes in smoke shown in the Fig. 3, suggest that additive of gas causes emission of particulate matter with smaller mass (diameter) with respect to emission at traditional fueling. However, these issues require another detailed investigations.

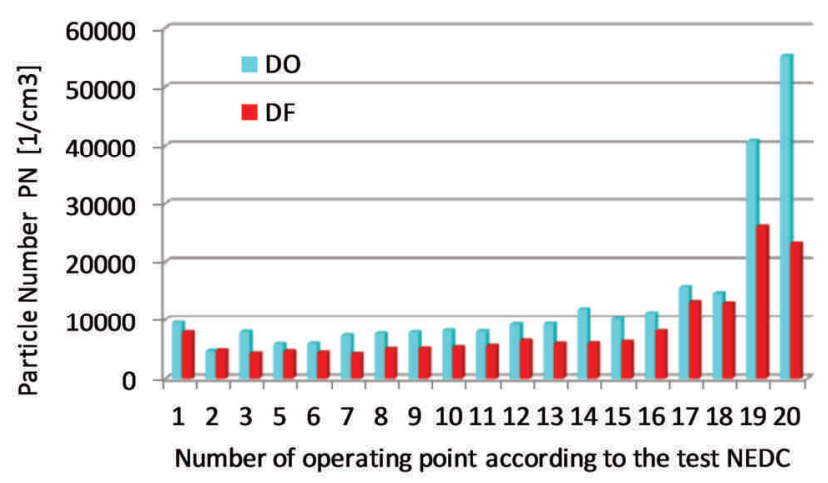

Fig. 4. Comparison of total PN number of particulate matter in exhaust gases of Fiat 1.3 MJT engine fueled traditionally and in dual fuel system: correction of air output, opening time of gas injectors 2.0
To important issues in operation of dual fuel engines belongs replacement of Diesel oil by gas. With constant opening time of gas injectors, such replacement is dependent on engine load, what is seen in the Fig. 5. Increase in share of gas at a higher engine loads would require active change in opening times of gas injectors, what complicates control of dual fuel engines. In addition, possibility of knocking combustion at maximal engine loads should also be taken into considerations. These issues were considered as the main assumptions adapted to the accomplished research work, in which share of gas at maximal engine loads was consciously limited.

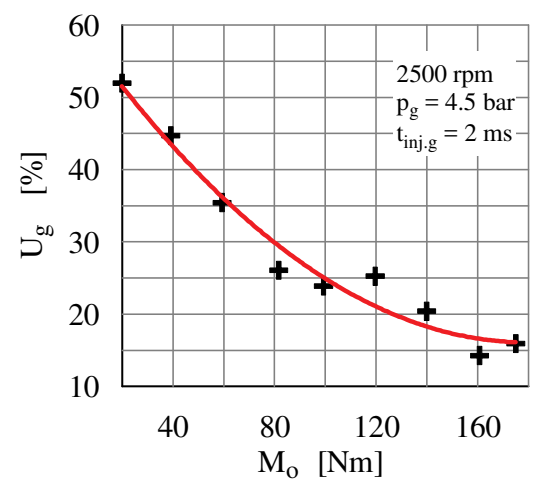

Fig. 5. Changes of gas energy share depending on engine load by fueling with diesel oil and dual fuel: gas injectors opening times $2 \mathrm{~ms}$, fixed gas supply pressure 4.5 bar

\section{Summary}

In the presented research work on dual fuel supply it have been used two controllers, factory made ECU controller for Diesel oil and additional controller for gas of OscarN Diesel SAS type, produced by Europe Gas Company. Control algorithms for gas as presented above were used in controlling of gas. Controlling of Diesel oil dose requires reprogramming of the factory controller or usage of additional controller for Diesel oil with proposed control algorithms, which will take over governing function over injection of liquid fuel after switching to dual fuel supply.

A special patch-type controller can be also produced for simultaneous control of injection of Diesel oil and gas. The basic functions of the Oscar-N Diesel SAS controller can be utilized in control section of gas, which have been tested and have confirmed correct and safe operation of the engine at gaseous fueling.

In adaptations of the engines to dual fuel supply, it is recommended to supply gas to intake manifold as close as possible to inlet valves. The system should be functional both with LPG gas and CNG or LNG. Depending on a type of used gas, a suitable components of the system like tank, reducer, high-pressure pipes, refueling valves and gas flow shut-off electro-valves should be used.

Performed research work has shown that there are real possibilities of reduction of the smoke and particulate matter in modern, high-speed compression ignition engines at low adaptation costs and small modifications in design of the engine. Additional aspect of proposed adaptation is possibility of alternate operation on Diesel oil or in dual fuel system, while maintaining all performance parameters 
of the engine, what could have important meaning in case of insufficient number of gas filing stations.

Obtained results of the research work show that dual fuel supply systems with small additive of gas can be also successfully used in future in low capacity engines, used as power units in passenger cars. It can be confirmed by results of the research work performed on Fiat 1.3 MJT engine.

\section{Acknowledgment}

The study was performed within framework of Research Project No. PBS1/A6/13/2012 „Reduction of smoke and particulate matter in exhaust gases of automotive engines with compression ignition, accomplished with use of CNG gas addition" financed by NCBiR.

\section{Bibliography}

[1] BARroso, P., RIBAS, X., DOMINGUES, J. et al. Study of dual-fuel (diesel+natural gas) particle mater and $\mathrm{CO}_{2}$ emissions of a heavy-duty diesel engine during transient operation. Combustion Engines. 2013, 153(2), 28-39.

[2] BEROUN, S., MARTINS, J. The development of gas (CNG, LPG and H2) engines for buses and trucks and their emission and cycle variability characteristics. SAE Technical Paper. 2001, 2001-01-0144.

[3] CLARK, N.N., ATKINSON, C.M., ATKINSON, R.J. et al. Optimized emission reduction strategies for dual fuel compression ignition engines running on natural gas and diesel. www.cemr.wvu.edu, 2002, 1-6.

[4] DAISHO, Y., TAKAHASHI, K. Controlling combustion and exhaust emissions in a direct-injection diesel engine dual fueled with natural gas. SAE Technical Paper. 1995, 952436

[5] EHSAN, M., BHUIJAN, S. Dual fuel performance of a small diesel engine for applications with less frequent load variations. International Journal of Mechanical \& Mechatronics Engineering IJMME. 2011, 9(10).

[6] FRIEDEMAN, Z. Gasmotoren. Vogel Buchverlag Wurzburg, 2001.

[7] GEBERT, K., BECK, J., BARKHIMER, R.L., WONG, H.C. Strategies to improve combustion and emission characteristics of dual-fuel pilot ignited natural gas engines. SAE Technical Paper. 1997, 971712, 79-87.

[8] KOWALEWICZ, A. Adaptacja silnika wysokoprężnego do zasilania gazem naturalnym. Czasopismo Techniczne Wydawnictwo Politechniki Krakowskiej. 2008, 7-M, 67-78.

[9] KOZAK, M. Studium wpływu komponentów tlenowych oleju napędowego na emisję toksycznych składników spalin z silników o zapłonie samoczynnym. Monografia habilitacyjna, Wydawnictwo Politechniki Poznańskiej, Poznań 2013.

Prof. Zdzislaw Stelmasiak, DSc., DEng. - Faculty of Mechanical Engineering and Computer Science at University of Bielsko-Biala.

e-mail:ZStelmasiak@ath.bielsko.pl

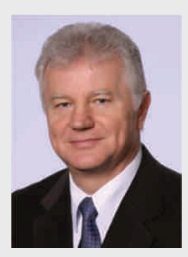

Jerzy Larisch, DEng. - Faculty of Mechanical Engineering and Computer Science at University of Bielsko-Biala.

e-mail:JLarisch@ath.bielsko.pl
[10] MATYJASIK, M. Aktywizacja procesu spalania mieszaniny gaz-powietrze w silnikach dwupaliwowych przez podział dawki inicjującej oleju napędowego. Praca doktorska. Bielsko-Biała 2012.

[11] MERKISZ, J., DASZKIEWICZ, P., IDZIOR, M. et al. Analiza ograniczenia emisji toksycznych składników spalin dwupaliwowego silnika o zapłonie samoczynnym. Logistyka. 2014, 6, 7260-7269.

[12] MERKISZ, J., PIELECHA, J. Emisja cząstek stałych ze źródeł motoryzacyjnych. Wydawnictwo Politechniki Poznańskiej. 2014, 309.

[13] MERKISZ, J., PIELECHA, J., ŁABĘDŹ, K., STOJECKI, A. Badania emisji spalin pojazdów o różnej klasie emisyjnej zasilanych gazem ziemnym. Prace Naukowe Politechniki Warszawskiej. Transport. 2013, 98, 463-472.

[14] PIETRAS, D., SOBIESZCZAŃSKI, M., ŚWIĄTEK, A., PAJDOWSKI, P. Dobór parametrów pracy silnika 1.3 multijet charakterystycznych dla testu jezdnego NEDC do badań rozwojowych. PTNSS P05-C065, PTNSS Kongres 2005.

[15] STELMASIAK, Z., LARISCH, J., PIETRAS, D. Wpływ dodatku gazu ziemnego na zadymienie spalin samochodowego silnika ZS. Combustion Engines.2015, 3.

[16] STELMASIAK, Z., LARISCH, J., PIETRAS, D. Wpływ dodatku gazu ziemnego na wybrane parametry pracy silnika Fiat 1.3 MultiJet zasilanego dwupaliwowo. Combustion Engines. 2015, 3.

[17] STELMASIAK, Z., LARISCH, J., PIETRAS, D. Wybrane problemy adaptacji samochodowego silnika o zapłonie samoczynnym do zasilania dwupaliwowego. Combustion Engines. 2015, 3.

[18] STELMASIAK, Z., LARISCH, J., PIETRAS, D. Some problems of controlling the car diesel engine powered dual fuel. Combustion Engines. 2015, 162(3), 1070-1081.

[19] Materiały firmy FIAT AUTO POLAND, 2014.

[20] Materiały techniczne firmy EuropeGAS, 2013.

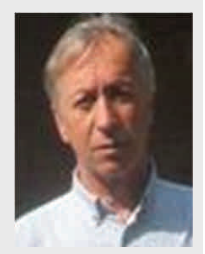

Dariusz Pietras, DEng. - Faculty of Mechanical Engineering and Computer Science at University of Bielsko-Biala.

e-mail:Pietras@ath.bielsko.pl

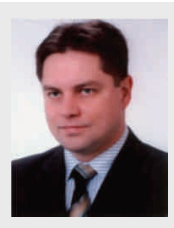

